\title{
"Craziness" and "Visions": experiences after a stroke
}

\author{
DOROTHEA WENDER
}

\section{Abstract}

For a stroke victim there may be at least three types of strange occurrences: incorrect saying, seeing, and thinking. To the patient only the third seems to be "crazy."

After a stroke (left hemisphere), which mainly produced serious aphasia, I (the patient) felt crazy two or three times when someone said something I expected him to say. On the other hand, my initial aphasic "gibberish speech" and an occasional false vision did not seem crazy. In my. case the vision is always a car or a child, seen on my extreme right, where I am otherwise blind from the stroke. I am always driving when it happens; in recent years this phenomenon occurs when I am tired or tense, or the light is poor. These rapid visions do not seem insane but merely physical problems in my eyes, much like ordinary people's dreams.

\section{Introduction}

Before my stroke I was a classics professor at an excellent women's college in New England. I considered "visions" (false appearances) as "crazy" and the persons who see ("seers") such things as "insane." Since, however, I have experienced unfortunate appearances of my own I now believe that, even though visions are (still) incorrect sights, the personality of the seer may well be perfectly normal. Perhaps, therefore, doctors might be interested in learning something about how a person with a logical sceptical personality feels when a part of her brain (her vision) works illogically.

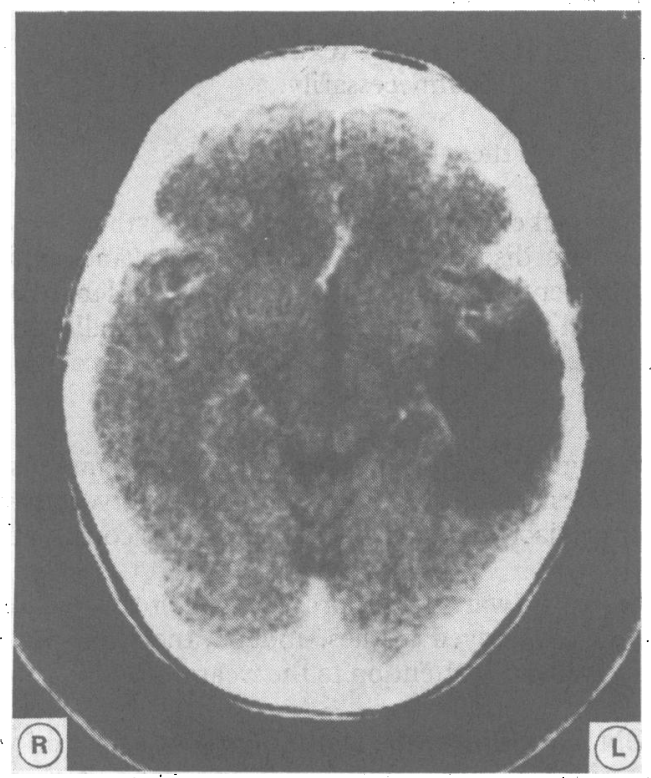

Initial computed tomogram.

My cerebral accident occurred when I was 45, on 17 November 1979; the result was a severe aphasia. Although I was not expected to improve well enough to teach any more, I am now teaching again and writing publishable works: scholarly material, two murder mysteries, and an article to be published in a neurological journal. I do not like hearing the word "miracle"; at

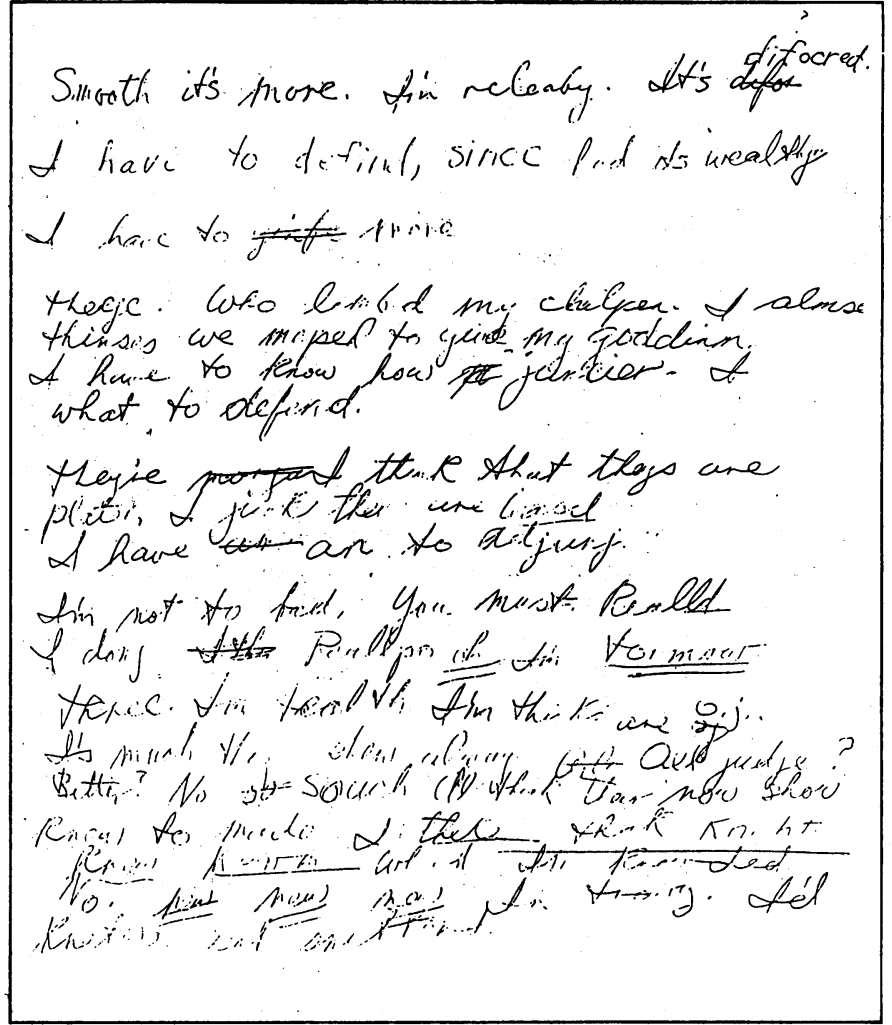

Actual writing in the beginning.

least one reason why I recovered so well was simply hard work, relearning English and ancient Greek. In fact I performed an experiment, working on Greek and not on Latin. The result was clear: my Latin has still not returned, but again I can read and teach Greek (Wender, in preparation).

Here I describe and briefly discuss several phenomena which occurred after my stroke, which could be called "insane" or "schizy."

\section{Incorrect speaking}

In the beginning my native language (English) was badly shattered, and like many aphasics I spoke "fluently" (that is, using sentences) but using many words which were either nonsense or ridiculously incorrect. For example, when I was asked to talk about Ronald Reagan's job I said something like "she's the kitchen of Imerca." Many people, even some neurologists and speech pathologists, would consider this "speech" as gibberish - that is, sounds without meaning. They would be wrong. I understood this question and "knew" the answer in my mind: he ("she") - a male-is the leader ("kitchen") of this country ("Imerca"). If I had been asked whether I would vote for Reagan I would definitely have shaken my head vigorously; if I had been asked to draw a symbol for Imerca I would have drawn a correct sketch of the flag or the eagle; every word I said meant something.

Several other recovered aphasics have mentioned similar beginnings after their strokes. This sort of speech might seem crazy to some listeners, but it is distinctly not so. It is not schizophrenic, but more like that of a foreigner who thinks his poor English vocabulary 
is as good as his actually excellent English grammar; after he sees the confused or embarrassed listeners he is likely to become much more silent. "Craziness," then, never seemed to me a part of my problems in talking or writing, although I was rather appalled much later when I looked at some of the pages I had written in the hospital (fig 2).

\section{Incorrect thinking}

I did consider myself crazy several (brief) times, roughly two months after my stroke. (Incidentally the only word for insane which I could think of spontaneously for several years was "cuckoo," although I hadn't forgotten any of the psychological material-for example, Freud's oedipal complex - which I taught when my students were reading Sophocles's Oedipus Tyrannus.) At the time I didn't tell anyone, but months later when my craziness had not recurred I asked my neurologist if my cuckoo moments had come from the cortisone or my own brain; he said it was the damaged brain. I wasn't thrilled by his answer, but was at least relieved that the cuckoo times had stopped. Those moments (two or three of them) happened at my college, when I met a colleague walking outside. Each time part of my mind (called $(a)$ in this description) thought what the person was going to say. One time I also hoped that he wouldn't say it. I became quite anxious when he actually said exactly who I had thought of. $(A)$ reacted to this occurrence by feeling that I could predict the future; this didn't please me (both $(a)$ and $(b)$ ) at all because at almost the same moment what seemed like another part of my brain $(b)$ said to $(a)$ that it was cuckoo.

$(B)$ said something like the following to $(a)$ : "Don't tell anybody what you just thought; that's crazy. You thought you were a prophet, whereas it was stupid. Anybody could predict that John would say 'Hi! How are you, Dory?' or, when it's raining, 'Isn't it a lousy day!' He always says things like that, so don't think you can tell the future; you're just sick in your mind." At that point (and I believe that was the last time when I had one of these cuckoo occurrences) sensible $(b)$ decided to persuade herself - that is, her (a)-that she wasn't a prophet. Therefore she made herself try to figure out what the next person-a much more unconventional guy in the English department - was going to say. It was a great success; my prediction was entirely wrong. Sick $(a)$ was relieved by $(b)$ 's good sense - and $(a)$ disappeared.

Next I $(b)$ worried about the fact that I seemed to have two "egos" at the moment: one cuckoo, the other sane. I thought about the paranoid person I knew and the fact that he never said anything cuckoo in front of the college president. "Hmm," I thought, "he must be like me, have a logical $(b)$ who makes his usual $(a)$-at least once in a while, when it really matters-not to talk crazy." Then I thought of "Eve White" and "Eve Black" in that movie which I had always considered Hollywood hokey, and wrong - the one with a woman who had three different personalities_-and ultimately I still haven't changed my feeling about that idea. Even so, my own prophetic moment was miserable; I have been a logical and sceptical person for my entire adult life.

\section{Incorrect seeing}

Before the stroke I would have said that visions (not seen by others) were about as crazy as anything possible. Now I feel, however, that at least the appearances of stroke victims are both not very important, and definitely not cuckoo. My rapid visions are always cars or small children, seen only in places which are reasonable - that is, cars arriving on side roads to the right; the children walking along the side of the street. They occur only when I am driving; they appear only for less than a second, disappear as soon as I move my head, and aren't frightening, just annoying. The

\section{Fabric dyes: Are they in the consumer's interest?}

We wish to challenge the idea that fabric dyes are harmless and are used merely as a response to consumer demand.

Textiles that are bleached and then printed or vat dyed sell for a higher price than textiles in their natural state.

Dyed clothes are more attractive to consumers and hence induce them to buy more clothes than they need.

These dyes are not necessary to the consumer. No one has assessed whether they increase the incidence of cancer, chronic toxicity, allergy, congenital malformations, heart disease, brain damage, or hyperactivity in children.

Tests conducted at a leading children's hospital in the United States show that hyperactive children are cured or improved by dressing them in undyed clothes.

The argument that dyes do not cause damage in mice, even in high concentrations, is untenable because mice are a different species. The thalidomide case shows that scientists can make major errors. Also, the mice were not tested for the "cocktail effect"' by being dressed in multicoloured clothes.

Consumers are not given a choice. Unbleached and undyed clothes are obtainable only at health food shops and are expensive because they cannot be mass produced.

By adding dyes to clothes manufacturers treble profits by a spurious form of "value added" technology. Many textile corporations employ so called textile designers, whose sole task is to colour fabrics unnecessarily.

Dyeing can conceal the natural flaws of textiles.

Dyed clothes make people more cheerful and therefore can mask psychiatric disorders such as depression and anxiety. Thus dyes "paper over" an important health problem that the National Health Service cannot afford to treat. Small wonder, then, that successive governments have taken no action on dyes.

Clothes are brighter then ever before, which accounts for the epidemic of obesity, malaise, flatulence, irritability, lethargy, indigestion, headache, dyspepsia, tiredness, and constipation.

Dyed clothes are no warmer and provide no more protection or concealment than undyed clothes. Indeed, their conspicuous colours may even draw attention to the wearer's body.

CAMPAIGN for additive free clothes for your sake and your children's welfare. COPY this leaflet and hand it to your friends.

Issued by DRAB, the Dye Related Allergies Bureau, c/o Camden Square, London NW1 9XA.

DRAB is a subsidiary of the Food Additives Research Team (FART).

For more information turn to page 1600 
right side of each eye is blind, which makes me anxious when I drive, especially when it's dark or I'm tired. All of this seems so reasonable, then, that it seems to me very much like what we all see in dreams, or ghosts seen in the closet by easily frightened children. There are, however, several additional points to mention.

Firstly, obviously some people see more unusual visions, even when theirs are also results from a stroke. A good, kind, and religious friend of mine was depressed (as all stroke patients feel in the first year). She also couldn't see on the right, like me, but (as she mentioned in a letter), several times she saw angels, dressed in white ... but only on the right.

Another point: $m y$ visions are more dramatic than the ghost in the closet type, or even the pictures in my dreams, which are rather vague, and never coloured. My ghost cars are not as clear as real cars right in front of my eyes, but they are not shadows, either. They have colour-one was a bright green-and are distinctly recent standard American automobiles; so far, none has been foreign, or red, or expensive. Not being a vehicle lover I cannot tell the reader any of the cars' makes; when I tried instantly to see a car in my mind's eye, however, my first reaction was a page in the automobile section in the Sunday Boston Globe. My next picture (very fleeting) was the used car lot in town, and I believe that one of its cars was a newly painted green. At any rate, I am never pleased by a false picture: it means I shouldn't be driving, but it also doesn't frighten, or suggest that I should found a new vehicle cult.

One final point: the blind side of my vision is neither black nor blank (that is, white). This is one of the major problems; since there is light and colour on both sides of my vision I often forget-even eight years after the stroke-that there may be real things which I am not seeing in an area where I think I can see. Very often I bump and break things on the right; sometimes I get confused when reading because I don't notice that there is another word at the end of the line. These things seem to happen from another fake vision of my brain; rather than seeing a blank area my eyes seem to "paint" a reasonable but fake picture. In the beginning I often saw people with only one eye (always their right, seen on my left, of course); now all people have two eyes.

But it is always possible that the second eye I see on someone's face is just as false (that is, not really seen) as someone else's angels. Now, I'm not a disciple of Plato, but when he says that we shouldn't necessarily believe our senses he certaintly has a point.

Wheaton College, Norton, Mass 02766, USA

DOROTHEA WENDER, PHiD, professor of classics

\title{
"Blow the Wind Southerly": extracts from a novel
}

\author{
THOMAS SHERWOOD
}

\section{London}

More rolls of lavatory paper and bars of soap. Peculiar packing for this trip-the usual two weeks' lecture tour to the States needed a few shirts, vests, pants, socks. He had learnt not to fuss around with too much: American universities didn't expect dinner jackets when they dined him out. And the hotels could always wash his things in a day. This time he is taking a much bigger suitcase. The bottom layer is already thick with packets of brown rice, flour and candles. Then the bars of soap. His clothes on top of this are only three or four inches deep, followed by the lavatory rolls. They started off as cylinders but squash up into flat, dumpy ovals when he forces the case shut, so there is room for more. The 15 paperback textbooks will go into the small case he can take with him on the 'plane. Together with his lecture slides and washing things. He leaves both cases open overnight, ready for a final check in the early morning before he leaves for the airport. He climbs into bed, tries to read Tom Paine's Rights of Man, fails, and drops asleep.

The airport is best reached by train. At 7 am London is still rubbing its eyes, and the large railway station is bright with empty space and sun. He puts his cases down at the gates to platform 13, and waits. Half exhilarated by the journey to come, the morning, the taste of the moment. The other half is foreboding. It is cold for early May. Who will come?

No one for a while. The occasional early traveller sees a man with one large and one small suitcase, standing with folded arms outside platform 13 . He seems to be somewhere around 40, unremarkably dressed except for wearing a hat. An early commuter train arrives on platform 12, and a few people walk off it, past him. The station clock moves to $710 \mathrm{am}$. At last someone approaches, a young man in jeans-looks like a student. He is clearly not sure of the man with folded arms, but after a few words both smile, and the young man pulls out three envelopes from his denim jacket. They are put into a large pocket of the small suitcase. As the two are about to say goodbye, a girl in her teens arrives, very pretty, hugs the young man her brother, and gives Philip more letters to pocket. Both leave at once, but Philip stays with his suitcases. In the next 20 minutes, as the cold spring morning tries to warm up, more people come one by one. They clearly do not know Philip, have arranged to meet the man at platform 13, and give him various envelopes, some quite thick. After a few words they hurry on. By 730 am the hurry is general, growing into the early London rush-hour. Trains arrive more frequently, spit out more people. Through the barrier, and down the stairs to the underground in that characteristic, look-neither-left-nor-right progress: anonymous Londoners sleepwalking their way to work. Philip wonders whether he too can go off now, in the opposite direction. One more messenger accosts him, black, the briefest of any of them, pressing a single letter into his hands. There is barely room in any suitcase pocket now. Philip picks up his bulging luggage, squeezes past the barrier and onto a train just leaving for the airport.

\section{Kisuti}

The session was cut short at noon by a messenger: the bishop's wife was waiting, when would Dr Edgehill come to see her in the officer-of-the-day's room?

The bishop's wife had fewer gold teeth than her husband but overall was bigger still. She sat surrounded by three adult daughters, and all were in quite expensive looking European dresses, with no holes at all. Bracelets clinked when they talked with their hands. The daughters saw themselves as so many interpreters. Philip quickly sent out two of them to lessen the chaos. They left reluctantly and stood in the doorway of the open room. Now and then a passerby would stop to look and listen with them, until shooed off by Philip. The officer of the day had wisely absconded long ago.

"Please ask your mother what she complains of."

There was lengthy and loud chatter between the two women. 